\title{
PENINGKATAN HASIL PEMBELAJARAN FUTSAL MELALUI PERMAINAN
}

(Studi Action Research Pada Siswa SMP Negeri 7 Padang

\author{
Eko Purnomo* \\ Universitas Negeri Jakarta \\ Email: ekopurnomo@fik.unp.ac.id
}

\begin{abstract}
Tujuan umum dari penelitian ini adalah untuk meningkatkan siswa hasil melalui penerapan pembelajaran futsal dengan menggunakan Pendekatan permainan. Selain itu, penelitian ini dilakukan untuk mendapatkan informasi mendalam tentang penerapan pembelajaran futsal dengan menggunakan pendekatan permainan. Desain penelitian ini adalah penelitian tindakan. Subyek dalam penelitian ini adalah 38 siswa dari kelas VIII di SMP Negeri 7 Padang.
\end{abstract}

Penelitian ini dilakukan 3 pertemuan di siklus ke I dan 1 pertemuan disiklus ke II. Adapun pada siklus I ditambahkan 2 kali pertemuan untuk melakukan tes awal dan tes akhi, sedangkan pada siklus ke II hanya ditambah 1 pertemuan untuk melakukan tes akhir. Setiap siklus terdiri dari tiga sesi. Siklus pertama menunjukkan bahwa melalui tindakan siswa dapat memotivasi diri. Dari siklus ke I ini hasilnya adalah $78,95 \%$ artinya perlu dilakukan siklus ke II. Pada siklus kedua sebagai refleksi dari siklus pertama juga menunjukkan bahwa tindakan memotivasi siswa. Hasil dari siklus kedua adalah $84,21 \%$ dan tidak perlu dilakukan siklus ke III.

Berdasarkan hasil penelitian ini dapat disimpulkan bahwa: (1) pembelajaran futsal dengan menggunakan pendekatan permainan meningkatkan hasil belajar siswa, (2) Pembelajaran futsal dengan menggunakan pendekatan permainan memotivasi siswa dan membuat siswa aktif dalam berpartisipasi dalam proses pembelajaran .

Kata kunci: Meningkatkan Hasil Belajar, Futsal, Pendekatan Permainan

\section{PENDAHULUAN}

Olahraga futsal saat ini bukan merupakan sesuatu yang aneh atau janggal di telinga kita, bahkan hampir semua orang dapat bermain futsal. Banyak alasan mengapa futsal sangat digemari saat ini, di antaranya dapat dimainkan kapan saja, tempat yang nyaman, serta tersedianya lapangan yang saat ini sudah ada di mana-mana. Futsal dimainkan oleh 5 orang dengan menggunakan ukuran lapangan yang lebih kecil dan menggunakan bahan yang berbeda dengan olahraga sepakbola.

\footnotetext{
* Eko Purnomo adalah mahasiswa Program Studi Pendidikan Olahraga, Program Pascasarjana, Universitas Negeri Jakarta.

Artikel ini diangkat dari tesis dengan judul yang sama, dengan pembimbing 1 Prof. Dr. Moch. Asmawi, M.Pd, dan pembimbing 2 Dr. Samsudin, M.Pd
} 
Olahraga futsal dimainkan secara kontak langsung sehingga banyak terjadi benturan, baik yang sengaja atau tidak disengaja. Oleh karena itu FIFA mambuat peraturan futsal yang digunakan untuk melindungi para pemain dari pemain lain yang melakukan permainan keras dan kasar.

Menurut Lhaksana Pada dasarnya permainan futsal cenderung lebih dinamis dan cepat sehingga sering terjadi pelanggaran yang tidak dilihat oleh para wasit yang sedang ada di lapangan. Dasar permaianan futsal tidak jauh berbeda atau bahkan hampir sama dengan olahraga pendahulunya atau sepakbola (football) seperti passing, dribbling, control, heading, shooting. ${ }^{1}$

Menggiring bola adalah menendang bola terputus-putus atau pelanpelan. Menggiring bola bertujuan untuk mendekati jarak ke saaran, melewati lawan dan menghambat permainan. ${ }^{2}$ Kaki yang digunakan dalam menggiring bola sama dengan kaki yang digunakan untuk menendang bola.

Pemain yang bersungguh-sungguh melatih kemampuan dalam penguasaan teknik futsal akan mampu menguasai teknik-teknik futsal lebih baik daripada pemain yang melakukan pola latihan dengan tidak bersungguh-sungguh. ${ }^{3}$

Teknik dasar yang satu ini disebut dengan passing. Dalam permainan futsal maupun sepabola, passing umumnya dilakukan dengan menggunakan kaki bagian dalam. Selain itu, passing juga dilakukan dengan menggunakan kaki bagian luar, tumit, serta ujung kaki. ${ }^{4}$ Sedangkan menurut Sahda Halim mengatakan passing yang baik akan membuat teman Anda akan mudah untuk menerima bola ${ }^{5}$.Tujuan dari mengoper bola (passing) adalah untuk menggulirkan bola dengan sebaik mungkin dan terkur sehingga memudahkan rekan/teman untuk menerimanya dengan baik. ${ }^{6}$

Menendang bola pada bagain-bagian tertentu juga menjadi bagian dari seni saat memberikan atau mengumpan bola kepada lawan. Bahkan sebagian pecinta futsal dan atau sepakbola punya kriteria sendiri dalam menciptakan passing yang indah namun tetap pada akurasi yang tepat. Perlu diingat juga komponen terpenting yang tidak kalah penting dalam melaksanan passing adalah penerima atau rekan yang akan kita umpan. Pemain yang akan menerima umpan dari kita sebisa mungkin mencari ruang terbuka agar mudah mendapat operan bola. Hal ini akan meudahkan tim dalam menguasai permainan.

1 Justinus Lhaksana, Taktik dan Strategi Futsal Modern. (Jakarta: Be Champion, 2011) h. 5.

${ }^{2}$ Asmar Jaya, Futsal: Gaya Hidup, Peraturan dan Tips-tips Permainan (Yogyakarta: Pustaka Timur, 2008), h. 66.

3 Muhammad Asriady Mulyono. Buku Pintar Panduan Futsal. (Cipayung: Laskar Aksara, 2014),h. 56.

${ }^{4}$ Ibid., h. 53.

${ }^{5}$ Sahda Halim. 1 Hari Pintar Main Futsal. (Jakarta: Media Presindo, 2009), h.75.

${ }^{6}$ Loc. cit., John D. Tenang. h. 83. 
Teknik memberikan bola kepada teman atau passing ini harus dikuasi oleh setiap pemain tanpa ada pengecualian, baik itu pemain bertahan ataupun pemain penyerang atau bahkan kipper. Selain itu, kemampuan seseorang dalam hal mengontrol bola juga harus ditingkatkan seiring waktu. Dan bahkan seorang pemain dituntut untuk mempunyai kemampuan mengontrol bola dan atau passing menggunakan kepala karena pada posisi atau keadaan tertentu, pemain diharuskan untuk memberikan atau membagi bola kepada teman dengan mengunakan kepala.

Menendang bola tidak harus kencang, kecuali saat mencetakgol. Bola harus ditendang pelan atau lazy pass. Ini sesuai dengan karakteristik futsal seagai olahraga yang mengutamakan passing game, yakni permainan dengan operan-operan pendek. ${ }^{7}$

Pemain yang memiliki teknik menandang dengan baik akan dapat bermain secara efisien. Tujuan menendang bola pada akhirnya untuk mengoper bola, menembak ke gawang, dan menyapu dan menggagalkan lawan.

Tenang mengatakan shooting adalah menendang bola dengan keras ke gawang, guna mencetak gol. Ini juga merupakan bagian tersulit karena perlu kematangan dan kecerdikan pemain dalam menendang bola agar tidak bisa dijangkau atau ditangkap oleh kiper. ${ }^{8}$

Futsal saat ini tidak hanya menjadi salah satu olahraga yang digemari oleh semua kalangan masyarakat. Futsal saat inijuga dijadikan wahana untuk mencari hiburan, melapas kepenatan dan bahkan pelakunya sendiri kini menjadikan futsal sebagai tempat untuk menjadi uang, artinya pelaku futsal atau pemain futsal juga dapat dikategorikan berkerja. Selain itu, futsal juga sudah masuk keranah pendidikan. Artinya futsal sudah dijadikan salahsatu dari matapelajaran yang diajarkan ditingkat sekolah.

Sekolah adalah sebagai lembaga formal dalam sistem pendidikan tidak telepas dari usaha-usaha peningkatan prestasi belajar anak didik. Kegiatan proses pembelajaran merupakan kegiatan pokok dalam keseluruhan kegiatan pendidikan di sekolah. Hal ini berarti berhasil tidaknya pencapaian tujuan pendidikan dalam bentuk terjadinya perubahan tingkah laku, pengetahuan, maupun keterampilan siswa tergantung pada bagaimana proses pembelajaran yang dialami oleh siswa sebagai anak didik.

Proses pembelajaran pendidikan jasmani guru memegang peranan dalam terlaksananya proses pembelajaran. Guru harus memperhatikan banyak hal berkenaan dengan siswa dalam pembelajaran pendidikan jasmani seperti aspek pertumbuhan dan perkembangan anak, dan karakteristik psikologi anak. Sebagaimana yang diuraikan dalam BSNP bahwa pendidikan jasmani, olahraga dan kesehatan merupakan media

\footnotetext{
${ }^{7}$ Loc. cit.,John D. Tenang. h. 74.

8 lbid., h. 84.
} 
untuk mendorong pertumbuhan fisik, perkembangan psikis, keterampilan motorik, pengetahuan dan penalaran, penghayatan nilai-nilai (sikap-mentalemosional- sportivitas-spritual-sosial), serta pembiasaan pola hidup sehat yang bermuara untuk merangsang pertumbuhan dan perkembangan kualitas fisik dan psikis yang seimbang. Oleh sebab itu, materi pelajaran, metode pembelajaran, sarana dan prasarana yang digunakan serta alat evaluasi harus disesuaikan dengan tahap perkembangan, karakteristik dan kebutuhan anak. Dengan cara demikian tujuan pembelajaran dapat tercapai secara optimal.

Guru pendidikan jasmani, olahraga dan kesehatan kebanyakan belum dapat menilai apa yang sebenarnya yang menjadi tujuan ketercapaian dari pembelajaran itu sendiri. Kebanyakan guru pendidikan jasmani, olahraga dan kesehatan hanya melihat dari sisi hasil permainan atau skor hasil pada suatu kejuaraan atau perlombaan tanpa memperhatikan tahapan-tahapan dari belajar itu sendiri. Seringkali guru pendidikan jasmani, olahraga dan kesehatan memberi pembelajaran futsal dengan metode konvensional yaitu dengan cara membariskan anak dan menyuruh anak tersebut bermain futsal sendiri layaknya pemain professional. Sesungguhnya cara tersebut tidak sepenuhnya salah, namun alangkah baiknya bila seorang guru pendidikan jasmani, olahraga dan kesehatan melihat proses belajar

Penulis akan meneliti bagaimana meningkatkan hasil belajar siswa pada materi pembelajaran dengan media pembelajaran yaitu belajar dengan memanfaatkan alat, teknologi, dan media lainnya dalam proses pembelajaran. Dengan penerapan model pembelajaran futsal diharapkan dapat memperbaiki kreativitas dan inovasi dalam mengajarkan pendidikan jasmani khususnya pada materi futsal. Pada dasarnya mengajar pada sekolah menengah pertama (SMP) harus mengacu pada kegiatan yang aman, nyaman dan menyenangkan.

Berdasarkan uraian di atas, maka sangat diperlukan upaya untuk perbaikan terhadap kekurangan-kekurangan dalam proses pembelajaran pendidikan jasmani. Khususnya untuk materi futsal dan lebih utamanya adalah bagian yang nantinya bisa dijadiakan acauan atau bisa menjadi patokan untuk mendidik anak atau pencarian bibit pemain futsal.

Berdasarkan masalah ini, perlu dilakukan penelitian terhadap keterampilan dribbling. Hal ini perlu mendapat perhatian karena dribbling sangat penting dalam permainan bolabasket karena dengan keterampilan dribbling yang baik dari seorang pemain ikut membantu persentase penguasaan bola yang lebih besar. Atas dasar faktor yang ada di atas peneliti menganggap pentingnya dilakukan sebuah penelitian untuk melihat dan mengungkapkan secara empiris hubungan kelentukan, kelincahan dan tingkat inteligensi terhadap keterampilan dribbling bolabasket. 


\section{METODOLOGI PENELITIAN}

Berdasarkan latar belakang penelitian yang telah diuraikan, maka penelitian ini bertujuan untuk peningkatan hasil belajar futsal pada siswa SMP Negeri 7 Padang dengan penerapan model pembelajaran futsal melalui permainan.

Penelitian ini dilaksanakan di SMP Negeri 7 Padang. Waktu pelaksanaan penelitian dilakukan pada tanggal November sampai dengan Desember 2015. Dengan frekwensi penelitian adalah 90 menit durasi sekali pertemuan dua kali minggu. Subjek penelitian dalam penelitian peningkatan hasil belajar futsal dengan penerapan permainan melalui pendekatan somatis adalah siswa kelas VIII yang berjumlah 38 orang yang ada di SMP Negeri 7 Padang.

Metode penelitian yang digunakan adalah metode penelitian tindakan (Action Research) dengan desain Kemmis dan Taggart. Pelaksanaan penelitian melibatkan rekan sejawat sebagai kolaborator dan guru kelas sebagai pelaksana tindakan. Hasil akhir dari kegiatan penelitian tindakan adalah peningkatan hasil belajar khususnya pembelajaran pendidikan jasmani, olahraga dan kesehatan pada materi futsal untuk siswa kelas VIII SMP Negeri 7 Padang.

Penelitian ini menggunakan siklus, dimana setiap siklus mempunyai langkah-langkah yang sistematis yang terdiri dari perencanaan tindakan, pelaksanaan, observasi dan refleksi.

Kemampuan dalam melakukan pembelajaran futsal dengan penerapan model pembelajaran melalui pendekatan permainan yang dilakukan siswa merupakan hasil yang diperoleh untuk mengetahui penguasaan pembelajaran yang diajarkan, kriteria keberhasilan di dalam proses pembelajaran ini sebagai berikut:

1. Hasil belajar siswa meningkat dalam pembelajaran pendidikan jasmani, olahraga dan kesehatan khususnya dalam materi futsal.

2. Guru mampu merencanakan dan menyajikan proses pembelajaran dengan penerapan model pembelajaran futsal melalui pendekatan permaian pada pembelajaran futsal.

3. Suasana belajar mengajar menjadi lebih menyenangkan, kondusif, dan tidak menimbulkan rasa jenuh bagi siswa.

4. Sebagian besar $(80 \%)$ siswa lulus dalam proses pembelajaran futsal.

5. Siswa menjadi termotivasi mengikuti proses pembelajaran futsal.

Data dari penelitian ini adalah seluruh unsur indikator yang berupa nilai pada kisi-kisi penilaian saat siswa melakukan test, dan data hasil evaluasi pelaksanaan dari catatan di lapangan, berfungsi sebagai bahan evaluasi pelaksanaan penerapan pembelajaran tindakan yang dilakukan pada setiap pertemuan. Adapun data penelitian terdiri dari dua jenis yaitu penelitian yang bersifat statistik deskriptif dan secara kualitatif. 
HASIL PENELITIAN

Tabel 1 Tes Awal Pembelajaran Futsal Secara Keseluruhan (Dribbling, Passing dan Shooting)

\begin{tabular}{|c|c|c|c|c|c|}
\hline $\begin{array}{c}\text { Kelas } \\
\text { Interval }\end{array}$ & $\begin{array}{c}\text { Batas } \\
\text { Bawah }\end{array}$ & $\begin{array}{c}\text { Batas } \\
\text { Atas }\end{array}$ & $\begin{array}{c}\text { Nilai } \\
\text { Tengah }\end{array}$ & $\begin{array}{c}\text { Frekuensi } \\
\text { Absolut (F) }\end{array}$ & $\begin{array}{c}\text { Frekuensi } \\
\text { Relatif (Fr)\% }\end{array}$ \\
\hline $41-45$ & 40,5 & 45,5 & 43 & 2 & 5,26 \\
\hline $46-50$ & 45,5 & 50,5 & 48 & 5 & 13,16 \\
\hline $51-55$ & 50,5 & 55,5 & 53 & 5 & 13,16 \\
\hline $56-60$ & 55,5 & 60,5 & 58 & 13 & 34,21 \\
\hline $61-65$ & 60,5 & 65,5 & 63 & 5 & 13,16 \\
\hline $66-70$ & 65,5 & 70,5 & 68 & 6 & 15,79 \\
\hline $71-75$ & 70,5 & 75,5 & 73 & 2 & 5,26 \\
\hline
\end{tabular}

Gambar 1 Tes AwalPembelajaran Futsal Secara Keseluruhan (Dribbling, Passing dan Shooting)

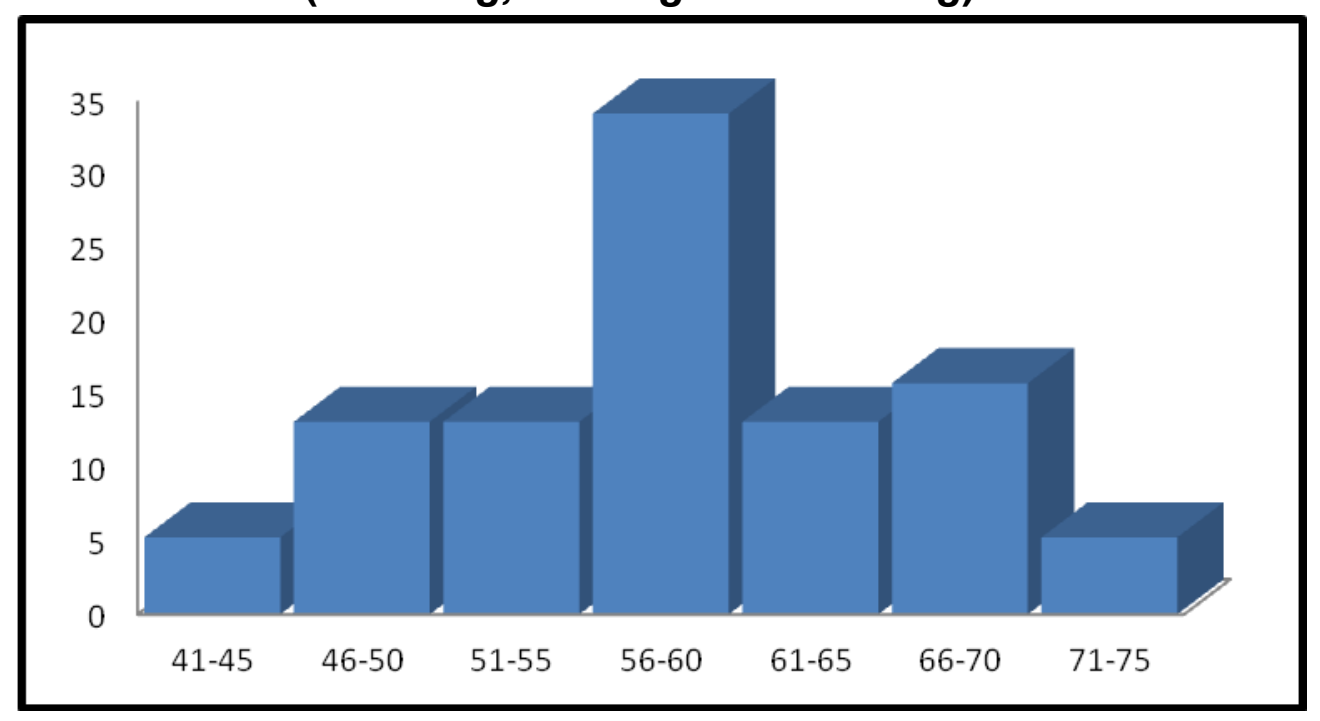

Tabel 2 Kategori Nilai Psikomotor Rata-rata Kelompok

\begin{tabular}{|c|c|c|}
\hline Nilai & Makna & Keterangan \\
\hline$\geq 80 \%$ & Lulus & Pembelajaran Berhasil \\
\hline $70-79 \%$ & Belum Lulus & PembelajaranTidak Berhasil \\
\hline $60-79 \%$ & Belum Lulus & Pembelajaran Tidak Berhasil \\
\hline $40-59 \%$ & Belum Lulus & Pembelajaran Tidak Berhasil \\
\hline $30-39 \%$ & Belum Lulus & Pembelajaran Tidak Berhasil \\
\hline$<29 \%$ & Belum Lulus & Pembelajaran Tidak Berhasil \\
\hline
\end{tabular}


Berdasarkan data di atas, dapat disimpulkan bahwa, pada pembelajaran futsal khususnya dribbling mendapatkan hasil sebesar $51,10 \%$ artinya hasil ini masih sangat jauh dari kelulusan. Pada kemampuan passing hasil yang diperoleh pada tes awal ini adalah sebsar $60,75 \%$, sedangkan untuk hasil tes awal shooting adalah sebesar $61,84 \%$. Dari hasil tersebut dapat disimpulkan bahwasannya dari masing-masing teknik dasar futsal tersebut belum kelompok masih belum mencapai target kelulusan yaitu sebesar minimal $80 \%$.

Dilihat secara kelompok, rata-rata nilai yang diperoleh adalah sebesar 57,89 . Jadi hasil tersebut juga belum mencapai nilai kelulusan. Berikut ini adalah rangkuman dari tes awal yang dilakukan.

Tabel 3 Rangkuman Hasil Tes Awal Pembelajaran Futsal

\begin{tabular}{|l|l|l|l|}
\hline $\begin{array}{c}\text { Aspek Yang } \\
\text { Dinilai }\end{array}$ & $\begin{array}{c}\text { Siswa Yang } \\
\text { Dinyatakan } \\
\text { Tuntas }\end{array}$ & $\begin{array}{c}\text { Siswa Yang } \\
\text { Dinyatakan } \\
\text { Belum Tuntas }\end{array}$ & Keterangan \\
\hline Dribbling & $1(2,63 \%)$ & $37(97,37 \%)$ & Belum Tuntas \\
\hline Passing & $1(2,63 \%)$ & $37(97,37 \%)$ & Belum Tuntas \\
\hline Shooting & $5(13,16 \%)$ & $33(86,84 \%)$ & Belum Tuntas \\
\hline Keseluruhan & $0(0 \%)$ & $38(100 \%)$ & Belum Tuntas \\
\hline
\end{tabular}

Selanjutnya mauk pada siklus I. Pelaksanaannya dikemas dalam bentuk model pembelajaran berbasis permainan terdiri atas a) permainan untuk meningkatkan kemampuan dribbling (1. bersatu teguh bercerai pushup, 2.kejar ekor sapi, 3. tangkap aku, 4. bisik-bisik tetangga, 5. jalan maut). b) permainan untuk meningkatkan kemampuan passing (1. tiki taka tuku, 2. move, 3. 4 saudara 4. pas, 5. jebakan tali). c) permainan untuk meningkatkan kemampuan shooting (1. kanan atau kiri, 2. buah jatuh, 3. tembak domba, 4. tembak cepat, 5. lingkar maut). Pembelajaran pada siklus satu ini diharapkan siswa dapat: 1) Menjelaskan teknik dribbling, passing, shooting dari awalan sampai sikap lanjutan. 2) Menjelaskan manfaat pembelajaran. 3) Memperagakan contoh gerakan. 4) Dapat bergerak bebas dan baik saat melakukan pembelajaran futsal. 
Tabel 4 Tes Akhir Siklus I Pembelajaran Futsal Secara Keseluruhan(Dribbling, Passing dan Shooting)

\begin{tabular}{|c|c|c|c|c|c|}
\hline $\begin{array}{c}\text { Kelas } \\
\text { Interval }\end{array}$ & $\begin{array}{c}\text { Batas } \\
\text { Bawah }\end{array}$ & $\begin{array}{c}\text { Batas } \\
\text { Atas }\end{array}$ & $\begin{array}{c}\text { Nilai } \\
\text { Tengah }\end{array}$ & $\begin{array}{c}\text { Frekuensi } \\
\text { Absolut (F) }\end{array}$ & $\begin{array}{c}\text { Frekuensi } \\
\text { Relatif (Fr)\% }\end{array}$ \\
\hline $60-64$ & 59,5 & 64,5 & 62 & 2 & 5,26 \\
\hline $65-69$ & 64,5 & 69,5 & 67 & 4 & 10,53 \\
\hline $70-74$ & 69,5 & 74,5 & 72 & 1 & 2,63 \\
\hline $75-79$ & 74,5 & 79,5 & 77 & 1 & 2,63 \\
\hline $80-84$ & 79,5 & 84,5 & 82 & 24 & 63,16 \\
\hline $85-89$ & 84,5 & 89,5 & 87 & 6 & 15,79 \\
\hline
\end{tabular}

Gambar 2 Tes Akhir Siklus I Pembelajaran Futsal Secara Keseluruhan(Dribbling, Passing dan Shooting)

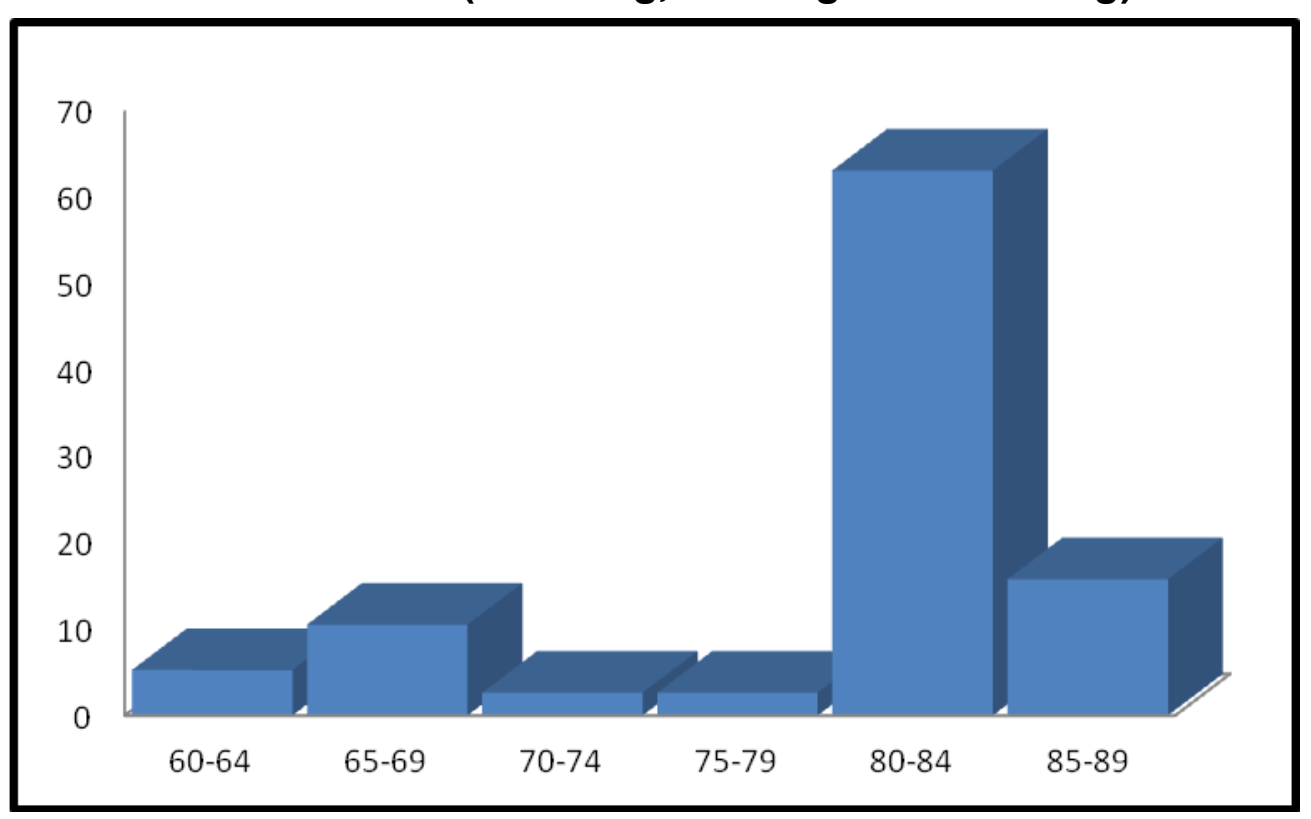

Berdasarkan tabel diatas maka dapat disimpulkan bahwa sebanyak 13 siswa atau $34,21 \% y a n g$ tuntassedangkan 25 siswa yang belum tuntas atau $65,79 \%$ dalam aspek dribbling atau dengan rata-rata nilai kelompok sebesar71,93, sedangkan untuk passingsebanyak 33 siswa atau $86,84 \%$ yang tuntas sedangkan 5 siswa yang belum tuntas atau $13,16 \%$ dalam aspek passingataudengan rata-rata nilai kelompok sebesar 83,33 , dan yang terakhir dalam aspek shooting sebanyak 31 siswa atau $81,57 \%$ yang tuntas sedangkan 7 siswa yang belum tuntas atau $18,42 \%$, jika dirata-ratakan nilai kelompok sebesar 83,56 . Jikadengan batas nilai minimal 80 maka secara kelompok aspek dribbling yang dinyatakan tidak tuntas, dan jika di lihat secara keseluruhan (dribbling, passing dan shooting) rata-rata nilai yang didapat sebesar 79,61. 
Tabel 5 Rangkuman Hasil Tes Siklus I Pembelajaran Futsal

\begin{tabular}{|l|l|l|l|}
\hline $\begin{array}{c}\text { Aspek Yang } \\
\text { Dinilai }\end{array}$ & $\begin{array}{c}\text { Siswa Yang } \\
\text { Dinyatakan } \\
\text { Tuntas }\end{array}$ & $\begin{array}{c}\text { Siswa Yang } \\
\text { Dinyatakan } \\
\text { Belum Tuntas }\end{array}$ & \multicolumn{1}{|c|}{$\begin{array}{c}\text { Nilai Rata- } \\
\text { rata }\end{array}$} \\
\hline Dribbling & $13(34,21 \%)$ & $25(65,79 \%)$ & 71,93 \\
\hline Passing & $33(86,84 \%)$ & $5(13,16 \%)$ & 83,33 \\
\hline Shooting & $31(81,58 \%)$ & $7(18,42 \%)$ & 83,56 \\
\hline Keseluruhan & $30(78,95 \%)$ & $8(21,05)$ & 79,61 \\
\hline
\end{tabular}

Setelah melaksanakan kegiatan pembelajaran dan menghitung data hasil penelitian, guru dan observer melakukan refleksi serta diskusi guna membahas permasalahan yang berhubungan dengan tindakan yang telah dilakukan oleh guru. Terlihat pada siklus I masih terdapat kekurangan baik dari guru maupun dari siswa. Oleh karena itu peneliti melakukan atau menerapkan siklus ke II untuk dilakukan tindakan dengan berbagai macam tindakan hasil dari evaluasi di siklus I.

a. Permainan 1 (Bersatu teguh bercerai push up)

- Bola yang awalnya menggunakan bola futsal, diganti dengan bola yang lebih besar yaitu bola basket.

- Siswa yang awalnya 10 orang setiap kelompok bermain, dikurangi menjadi 5 orang, untuk meningkatkan efektifitas permainan.

b. Permainan 2 (Kejar ekor sapi)

- Siswa yang awalnya 10 orang setiap kelompok bermain, dikurangi menjadi 5 orang, untuk meningkatkan efektifitas permainan.

- Bola yang awalnya menggunakan bola futsal, diganti dengan bola yang lebih besar yaitu bola basket.

c. Permainan 4 (Jalan maut)

- Bola yang awalnya menggunakan bola futsal, diganti dengan bola yang lebih besar yaitu bola basket.

- Lapangan yang digunakan lebih besar dari sebelumnya.

d. Permainan 3 (Race)

- Permainan ini adalah bentuk perubahan dari permainan "kejar aku". Peneliti menganggap permainan sebelumnya dianggap kurang tepat jika diterapkan pada siswa SMP.

e. Permainan 5 (C.I.L)

- Permainan ini adalah bentuk perubahan dari permainan "bisikbisik tetangga". Peneliti menganggap permainan sebelumnya dianggap kurang tepat jika diterapkan pada siswa SMP 
Tabel 6 Tes Akhir Siklus II Pembelajaran Futsal Secara Keseluruhan (Dribbling, Passing dan Shooting)

\begin{tabular}{|c|c|c|c|c|c|}
\hline $\begin{array}{c}\text { Kelas } \\
\text { Interval }\end{array}$ & $\begin{array}{c}\text { Batas } \\
\text { Bawah }\end{array}$ & $\begin{array}{c}\text { Batas } \\
\text { Atas }\end{array}$ & $\begin{array}{c}\text { Nilai } \\
\text { Tengah }\end{array}$ & $\begin{array}{c}\text { Frekuensi } \\
\text { Absolut (F) }\end{array}$ & $\begin{array}{c}\text { Frekuensi } \\
\text { Relatif (Fr)\% }\end{array}$ \\
\hline $65-68$ & 65,5 & 68,5 & 66,6 & 1 & 2,63 \\
\hline $69-72$ & 79,5 & 72,5 & 70,5 & 1 & 2,63 \\
\hline $73-76$ & 73,5 & 76,5 & 74,5 & 3 & 7,89 \\
\hline $77-80$ & 77,7 & 80,5 & 78,5 & 4 & 10,53 \\
\hline $81-84$ & 81,5 & 84,5 & 82,5 & 14 & 36,84 \\
\hline $85-88$ & 85,5 & 88,5 & 86,5 & 10 & 26,32 \\
\hline $89-92$ & 89,5 & 92,5 & 90,5 & 5 & 13,16 \\
\hline
\end{tabular}

Gambar 3 Tes Akhir Siklus II Pembelajaran Futsal Secara Keseluruhan (Dribbling, Passing dan Shooting)

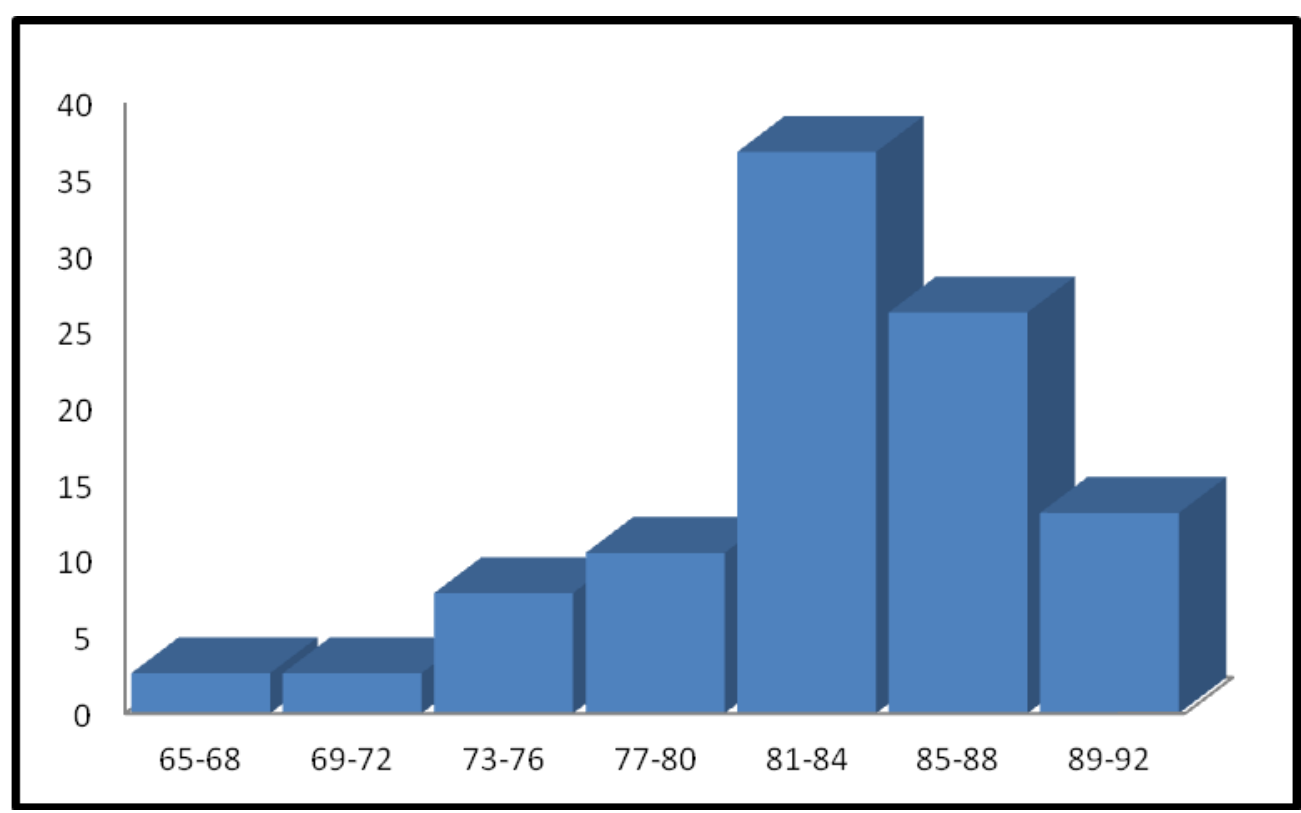

Berdasarkan tabel dan gambar diagram diatas dapat kita simpulkan bahwa siswa yang tuntas sebanyak 33 siswa atau sekitar $86,84 \%$ dengan nilai minimum adalah 66,67 , dan siswa yang tidak tuntas adalah sekitar 5 siswa atau sekitar $13,16 \%$, atau secara keseluruhan persentase dari tes akhir pembelajaran futsal (dribbling, passing dan shooting) atau nilai ratarata kelompok adalah sebesar 83,26. Dengan hasil tersebut maka pembelajaran dapat dikatakan tuntas, memang ada beberapa siswa yang tidak lulus dalam pembelajaran, tetapi hal tersebut dalam pembelajaran dikatakan wajar. 


\section{PEMBAHASAN}

Hasil tes awal yang dilakukan oleh peneliti, diperoleh data awal tes futsal (dribbling, passing dan shooting) sebagai berikut ini, siswa yang memperoleh nilai $0-79$ sebanyak38 siswa atau $100 \%$ dan masih belum ada siswa yang memperoleh nilai 80 atau 80 ke atas. Dengan kata lain nilai ratarata kelompok yang diperoleh adalah sebesar 57,89. Jika dilihat rincian dari aspek penilaian yang diperoleh adalah sebagai berikut ini.

- Dribbling: 51,10 (37 siswa belum tuntas atau 97,37\% dan 1 siswa yang tuntas atau $2,63 \%$ )

- Passing: 60,75 (37 siswa belum tuntas atau 97,37\% dan 1 siswa yang tuntas atau $2,63 \%)$

- Shooting:61,84 (33 siswa belum tuntas atau $86,84 \%$ dan 5 siswa yang tuntas atau $13,16 \%$ )

Dengan demikian sesuai data diatas dapat dikatakan bahwa, hasil belajar futsalmasih sangat rendah, hal ini disebabkan karena metode pembelajaran yang diterapkan masih dalam masa penyesuaian bagi siswa, kurangnya pendekatan antara guru dengan siswa dan metode pembelajaran yang diterapkan guru pada setiap pertemuan adalah menjelaskan materi, pemanasan, perenggangan dan jarang diberikan game atau permainan yang mendukung materi pelajaran.

Hasil tes siklus I yang dilakukan oleh peneliti, diperoleh data awal tes futsal (dribbling, passing dan shooting) sebagai berikut ini, siswa yang memperoleh nilai $0-79$ sebanyak8 siswa atau $21,05 \%$, sementara siswa yang memperoleh nilai 80 keatas sebanyak 30 siswa atau $78,95 \%$ dengan kata lain nilai rata-rata kelompok yang diperoleh adalah sebesar 79,61. Jika dilihat rincian dari aspek penilaian yang diperoleh adalah sebagai berikut ini.

- Dribbling: Nilai rata-rata kelompok71,93 (13 siswa tuntas atau $34,21 \%$ dan 25 siswa belum tuntas atau $65,79 \%)$

- Passing: Nilai rata-rata kelompok 83,33 (33 siswa tuntas atau $86,84 \%$ dan 5 siswa belum tuntas atau 13,16\%)

- Shooting:Nilai rata-rata kelompok 83,56 (31 siswa tuntas atau $81,58 \%$ dan 7 siswa belum tuntas atau $18,42 \%)$

Dengan demikian sesuai data yang diperoleh diatas dapat dikatakan bahwa hasil belajar futsalsudah mengalami perubahan, namun belum mencapai target ketuntasan karena dari keseluruhan siswa hanya 78,95\% yang tuntas sementara yang yang belum tuntas adalah sebesar $21,05 \%$ siswa. Hal ini dikarenakan beberapa siswa masih banyak yang belum tuntas di aspek dribbling hal tersebut juga mengakibatkan hasil nilai yang diperoleh secara kelompok pada aspek dribbling juga jelum mencapai nilai ketuntasan yaitu 80 keatas. Hal tersebut memaksa peneliti untuk mengevaluasi 
pembelajaran yang dilakukan, diantaranya adalah dengan memodivikasi permainan dari siklus I atau merubah permainan yang ada.

Hasil tes siklus II yang dilakukan oleh peneliti, diperoleh data tes futsal (dribbling) sebagai berikut ini, 33 siswa tuntas atau $86,84 \%$ dan 5 siswa belum tuntas atau $13,16 \%$. Jadi jika diakumulasikan keseluruhan (dribbling, passing dan shooting)siswa yang memperoleh nilai 079sebanyak6 siswa atau $15,79 \%$, sementara siswa yang memperoleh nilai $80 \mathrm{ke}$ atas sebanyak 32 siswa atau $84,21 \%$ dengan kata lain nilai rata-rata kelompok secara keseluruhan (dribbling, passing dan shooting)yang diperoleh adalah sebesar 83,26. Jika dilihat rincian dari aspek penilaian yang diperoleh adalah sebagai berikut ini.

- Dribbling: Nilai rata-rata kelompok 71,93 (33 siswa tuntas atau $86,84 \%$ dan 5 siswa belum tuntas atau $13,16 \%)$

- Passing: Nilai rata-rata kelompok 83,33 (33 siswa tuntas atau $86,84 \%$ dan 5 siswa belum tuntas atau 13,16\%) (data diambil dari siklus I)

- Shooting: Nilai rata-rata kelompok 83,56 (31 siswa tuntas atau $81,58 \%$ dan 7 siswa belum tuntas atau 18,42\%) (data diambil dari siklus I)

Dengan demikian dari data yang diperoleh diatas bahwa pada siklus II siswa telah mencapai target yang dicapai yaitu secara keseluruhan $80 \%$ ketuntasan dan pada siklus II ini siswa telah mendapat $84,21 \%$ melebihi target yang dicapai.

Pada penelitian yang dilaksanakan, sebenarnya peneliti sudah mencapai target yang ingin diharapakan, baik target dari peneliti itu sendiri ataupun target yang diinginkan oleh pihak sekolah. Akan tetapi pada hasil penelitian yang diperoleh baik pada siklus I dan siklus II masih terdapat siswa yang belum mencapai target minimal nilai ketuntasan (80). Pada kejadian ini sebenarnya peneliti tidak perlu untuk melaksanakan pada siklus ke III untuk meluluskan nilai siswa yang belum lulus atau tuntas, akan tetapi untuk mengangkat nilai siswa dan membuat siswa tersebut tuntas dalam pembelajaran, maka perlu dilaksanakan proses remedial.

Remedial yang akan dilakukan adalah diluar penelitian, dan subjeknya hanya siswa yang belum tuntas pada hasil keseluruhan. Artinya, pada siklus I siswa yang belum tuntas akan dilakukan tindakan di siklus ke II, akan tetapi bagi siswa yang tetap atau masih belum tuntas, akan dilakukan remedial. 
Tabel 7 Hasil Remedial Pembelajaran Futsal

Secara Keseluruhan (Dribbling, Passing dan Shooting)

\begin{tabular}{|c|c|c|c|c|c|}
\hline $\begin{array}{c}\text { Kelas } \\
\text { Interval }\end{array}$ & $\begin{array}{c}\text { Batas } \\
\text { Bawah }\end{array}$ & $\begin{array}{c}\text { Batas } \\
\text { Atas }\end{array}$ & $\begin{array}{c}\text { Nilai } \\
\text { Tengah }\end{array}$ & $\begin{array}{c}\text { Frekuensi } \\
\text { Absolut (F) }\end{array}$ & $\begin{array}{c}\text { Frekuensi } \\
\text { Relatif (Fr)\% }\end{array}$ \\
\hline $0-84$ & 79,5 & 84,5 & 82 & 20 & 52,63 \\
\hline $85-89$ & 84,5 & 89,5 & 87 & 16 & 42,11 \\
\hline $90-94$ & 89,5 & 94,5 & 92 & 2 & 5,26 \\
\hline
\end{tabular}

Gambar 4 Tes Akhir Siklus II Pembelajaran Futsal Secara Keseluruhan (Dribbling, Passing dan Shooting)

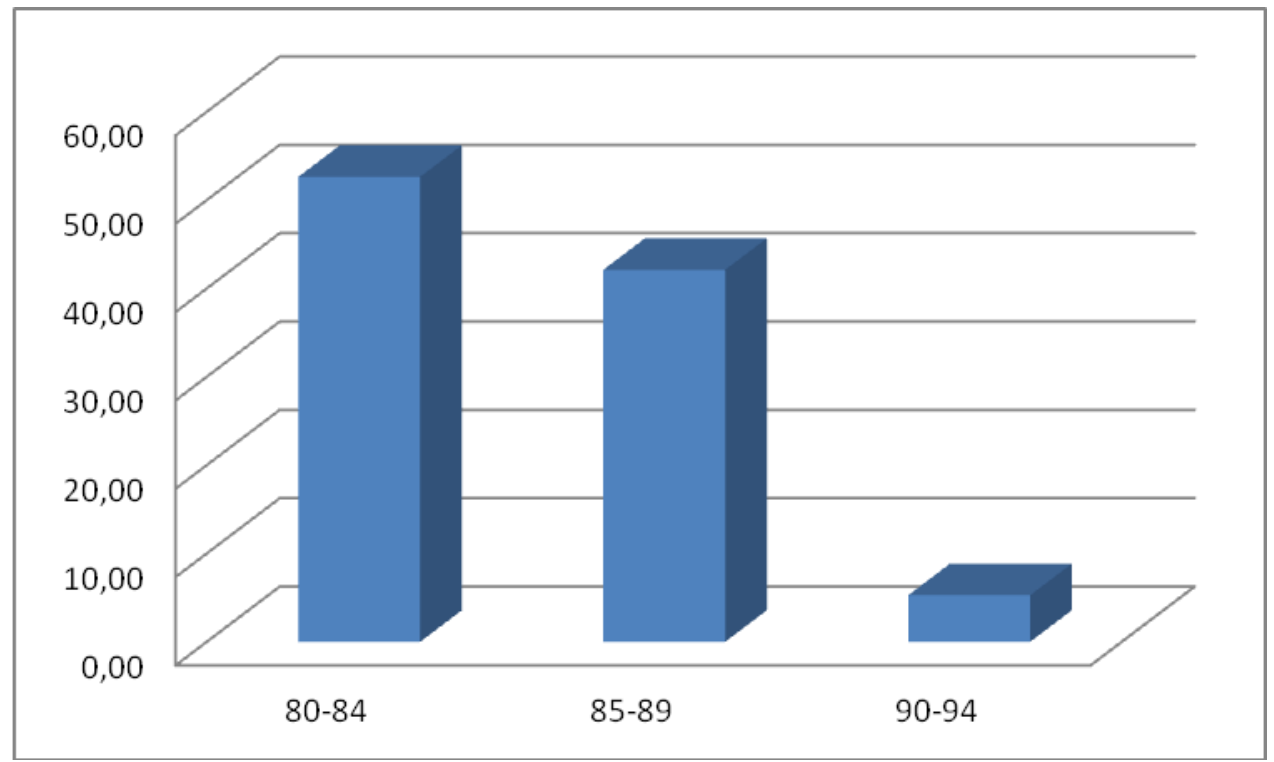

Berdasarkan tabel dan gambar diagram diatas dapat kita simpulkan bahwa siswa yang tuntas sebanyak 38 siswa atau 100\% dengan nilai minimum adalah 83,33, atau hasil secara keseluruhan tes akhir pembelajaran futsal (dribbling, passing dan shotting) atau nilai rata-rata kelompok adalah sebesar 85,23 . Dengan hasil tersebut maka pembelajaran dapat dikatakan tuntas $100 \%$. 


\section{KESIMPULAN}

Berdasarkan penelitian yang telah diuraikan di atas, maka dapat diambil kesimpulan:

Berdasarkan hasil penelitian yang telah dipaparkan, secara umum dapat disimpulkan bahwa adanya peningkatan hasil belajar siswa dengan model pembelajaran futsal melalui pendekan permainan pada pembelajaran pendidikan jasmani siswa kelas VIII SMP N 7 Padang.

Perencanaan kegiatan pembelajaran pada siklus pertama dan kedua peneliti melaksanakan berbagai kegiatan pembelajaran yang disyaratkan untuk menyelenggarakan kegiatan pembelajaran yang efektif. Peneliti memberikan arahan kepada siswa sesuai dengan rencana pembelajaran. Berdasarkan hasil di atas pada siklus pertama siswa cukup antusias dalam mengikuti pembelajaran futsal.

Sesuai dengan refleksi, harapan dari peneliti $80 \%$ siswa aktif, serta antusias dalam mengikuti kegiatan pembelajaran. Sehingga pada siklus kedua peneliti berhasil memperbaiki pendekatan pembelajaran dengan memberikan pengertian dan pengarahan sesuai kondisi siswa pada saat itu, selain itu peneliti juga melakukan perubahan dan penambahan beberapa alat pembelajaran yang digunakan. Hasilnya adalah 33 siswa aktif dalam mengikuti pembelajaran futsal, 5 siswa bersikap kadang aktif dan kadang acuh. Berdasarkan hasil belajar siswa pada siklus pertama nilai rata-rata kelas pembelajaran futsal adalah 79,61 dan hasil belajar siswa pada siklus kedua adalah 83,28 dengan persentase ketuntasan $84,84 \%$ siswa yang lulus.

Guna menunjang hasil akhir yang baik atau untuk menuntaskan siswa yang belum tuntas, maka dilakukanlah remedial kepada siswa yang belum tuntas pada hasil akhir dalam penelitian tersebut.

\section{Daftar Pustaka}

Asmar Jaya, Futsal: Gaya Hidup, Peraturan dan Tips-tips Permainan Yogyakarta: Pustaka Timur, 2008.

John Tenang, D. Mahir Bermain Futsal. Jakarta: DAR! Mizan, 2008.

Justinus Lhaksana, Taktik dan Strategi Futsal Modern. Jakarta: Be Champion, 2011.

Muhammad Asriady Mulyono. Buku Pintar Panduan Futsal. Cipayung: Laskar Aksara, 2014.

Sahda Halim. 1 Hari Pintar Main Futsal. Jakarta: Media Presindo, 2009. 